\title{
Chronic exposure to emissions from photocopiers in copy shops causes oxidative stress and systematic inflammation among photocopier operators in India
}

\author{
Nithya Elango*, Vallikkannu Kasi, Bhuvaneswari Vembhu and Jeyanthi Govindasamy Poornima
}

\begin{abstract}
Background: We assessed indoor air quality in photocopier centers and investigated whether occupational exposure to emissions from photocopiers is associated with decline in lung function or changes in haematological parameters, oxidative stress and inflammatory status.

Methods: Indoor air quality was monitored in five photocopier centers. Pulmonary function was assessed by spirometry in 81 photocopier operators (64 male and 17 female) and 43 healthy control (31 male and 12 female) subjects. Hematological status, serum thio-barbituric acid reactive substances (TBARS), total ferric reducing antioxidant capacity (FRAC), leukotriene $\mathrm{B}_{4}\left(\mathrm{LTB}_{4}\right)$, 8-isoprostane, $\mathrm{C}$ reactive protein (CRP), interleukin 8 (IL-8), clara cell protein (CC-16), intercellular adhesion molecule 1 (ICAM-1) and eosinophilic cationic protein (ECP) were analyzed. Relationships between cumulative exposure, lung function and inflammatory markers were assessed.

Results: $\mathrm{PM}_{10}$ and $\mathrm{PM}_{2.5}$ were above the permissible levels in all the photocopier centers, whereas the levels of carbon monoxide, nitrogen oxides, ozone, sulphur dioxide, lead, arsenic, nickel, ammonia, benzene and benzo(a) pyrene were within Indian ambient air quality standards. Lung function was similar in the photocopier operators and control subjects. Serum TBARS was significantly higher and FRAC was lower among photocopier operators when compared to healthy controls. Plasma IL-8, $\mathrm{LTB}_{4}, \mathrm{ICAM}-1$ and ECP were significantly higher in the photocopier exposed group.

Conclusions: Photocopiers emit high levels of particulate matter. Long term exposure to emissions from photocopiers was not associated with decreased lung function, but resulted in high oxidative stress and systemic inflammation leading to high risk of cardiovascular diseases.
\end{abstract}

Keywords: Photocopiers, Particulate matter, Biomarkers, Lung function, Occupational exposure, Toner

\section{Background}

Photocopiers are considered as essential amenities at offices and business establishments. The world printing machinery and supplies industry is expected to exceed $\$ 21$ billion by 2015 . In the last two years alone, more than 250 million photocopiers have been sold all over the world. The market is driven by demand for digital colour presses, specialty printers and inkjet printers.

\footnotetext{
* Correspondence: nithya.s.chidambaram@gmail.com

Department of Biochemistry, Biotechnology and Bioinformatics

Avinashilingam Institute for Home Science and Higher Education for Women

Coimbatore, Tamilnadu, India
}

The changing landscape of technology also fuels the printing machinery and supplies industry with new products, innovation and dynamic media giving the market a significant boost [1]. Consequently, the number of people operating photocopiers around the world may run into millions.

Despite the advantages and commercial benefits of photocopiers, they are also sources of air pollution. During operation, photocopiers emit toner particles, toxic gases namely ozone, nitrogen dioxide, volatile organic compounds, semi-volatile organic compounds, radiation, 
particulate matter, paper particles, nano particles and extremely low-frequency electromagnetic fields [2-4].

Till this date, health studies on occupational exposure to emissions from photocopiers are inconclusive and not comprehensive. Several studies have associated chronic exposure to emissions from photocopiers in occupational settings with symptoms like breathlessness, non-allergic rhinitis, sore throat, cough, asthma, pseudo allergic inflammation of the respiratory tract, upper respiratory tract infections, skin and eye irritations, headache, sick building syndrome, siderosilicosis, granulomotous pneumonitis and sarcoidosis [5-9]. A number of authors have reported elevated DNA damage among operators in photocopier centers [10-13]. However, others [2] suggested current exposure levels in photocopier centres may be sufficiently safe in well controlled work environments.

Photocopier toners are chief components of photocopier emissions. The effects of toner exposure have been extensively studied in cell culture, animal models and operators in toner manufacturing units and delineate contradictory results. Studies [14] in cell lines reported that individual toners are genotoxic. Animal studies found toners to be toxicologically inert and non carcinogenic $[15,16]$. However, intra-tracheal instillation of very high doses of toner powder produced significantly increased lung tumor rates in rats [17-19].

Sub-mesothelial deposition of carbon nanoparticles in the peritoneum of toner dust exposed worker was reported [20]. When respiratory health of workers in toner manufacturing units were assessed, studies suggested deterioration of respiratory health related to toner dust exposure was less likely to occur in current well controlled work environments [21-23].

In this study we assessed indoor air quality in photocopier centers. We investigated, in a cross sectional design, whether occupational exposure to emissions from photocopiers is associated with impaired lung function and/or induce changes in haematological, oxidative and inflammatory status. This study was carried out in Coimbatore, a metropolitan city in south India between January 2011 and February 2012.

\section{Materials and methods}

\section{Air quality monitoring}

Indoor air quality was monitored in selected photocopier centers as per Indian Standard guidelines (IS 5182) [24]. Air sampling was conducted at 5 photocopy centers in Coimbatore, during September 2012. Table 1 lists the methods used to assess the different various air quality parameters.

Measurements were made on working days for a period of 8 hours by an ISO 2001 certified commercial laboratory. Indoor air quality assessment was carried out by positioning the sampling equipment directly opposite to the photocopier(s) in all the centers. In Coimbatore, most
Table 1 Methods followed to assess indoor air quality in photocopier centers

\begin{tabular}{|c|c|c|}
\hline $\begin{array}{l}\text { Air quality } \\
\text { parameters }\end{array}$ & Air flow rate & Method \\
\hline Carbon monoxide & $\begin{array}{l}40 \mathrm{~mL} / \text { minute } \\
\text { for } 1 \text { hour }\end{array}$ & $\begin{array}{l}\text { Indicator tube using } \\
\text { silicomolybdate [25] }\end{array}$ \\
\hline Nitrogen dioxide & $\begin{array}{l}200 \mathrm{~mL} / \text { minute } \\
\text { for } 4 \text { hours }\end{array}$ & $\begin{array}{l}\text { Spectrophotometric } \\
\text { method }[26,27]\end{array}$ \\
\hline Ozone & $\begin{array}{l}1 \mathrm{~L} / \text { minute for } \\
1 \text { hour }\end{array}$ & Chemical method [28] \\
\hline $\begin{array}{l}\text { Fine particulate } \\
\text { matter }\left(\mathrm{PM}_{2.5}\right)\end{array}$ & $\begin{array}{l}1.5 \mathrm{~L} / \text { minute for } \\
8 \text { hours }\end{array}$ & Gravimetric method [29] \\
\hline $\begin{array}{l}\text { Particulate matter } \\
\left(\mathrm{PM}_{10}\right)\end{array}$ & $\begin{array}{l}1000 \mathrm{~L} / \text { minute } \\
\text { for } 8 \text { hours }\end{array}$ & Gravimetric method $[27,30]$ \\
\hline Sulphur dioxide & $\begin{array}{l}1 \text { litre/minute } \\
\text { for } 30 \text { minutes }\end{array}$ & $\begin{array}{l}\text { West and Gaeke method } \\
{[27,31]}\end{array}$ \\
\hline Lead, Arsenic, Nickel & $\begin{array}{l}1 \text { litre/minute } \\
\text { for } 8 \text { hours }\end{array}$ & $\begin{array}{l}\text { Atomic Atomic Spectroscopy } \\
\text { after absorption on filter } \\
\text { paper }[30,32]\end{array}$ \\
\hline Ammonia & $\begin{array}{l}1 \text { litre/minute } \\
\text { for } 1 \text { hour }\end{array}$ & Indophenol method [27] \\
\hline $\begin{array}{l}\text { Benzene, } \\
\text { Benzo(a)pyrene }\end{array}$ & $1.2 \mathrm{ml} / \mathrm{minute}$ & $\begin{array}{l}\text { Active sampling by activated } \\
\text { charcoal tube, desorbed by } \\
\text { Carbondisulphide followed by } \\
\text { Gas chromatography with } \\
\text { phenyl dimethyl polysiloxane } \\
\text { column and flame ionisation } \\
\text { detector }[33,34]\end{array}$ \\
\hline
\end{tabular}

photocopy centers are located at ground level. The width of each photocopy center is approximately 10 meters. A typical photocopier center consists of a concrete building with walls on three sides. The fourth side consists of a retractable shutter which is closed only during out of business hours. Typical interior materials used in photocopy centers include cement floor, painted concrete ceiling, painted concrete walls and metal shutters. Usually some metal desks, chairs, one to two computers, laminating and binding machines, are present in the confined space of a photocopy center. Basic information of the photocopy centers, including room dimensions, environmental conditions, business hours, types of ventilation, number of photocopiers, number of copies made on an average work day and the presence of other VOC-emitting sources were collected. Table 2 lists the physical characteristics of the photocopy centers. Table 3 lists the number of photocopiers present in each copy shop and the details about the toners used. Facsimile machines, color photocopiers and laser printers were also seen in some centers, but their use was very rare. Therefore, the current study focused on the emission from black-and-white photocopiers.

\section{Study population}

The eligible population in the selected region consisted of photocopier operators who had worked in photocopier 
Table 2 Physical characteristics of photocopy centers where indoor air quality was measured

\begin{tabular}{|c|c|c|c|c|c|c|c|c|c|}
\hline $\begin{array}{l}\text { Copy } \\
\text { center }\end{array}$ & $\begin{array}{l}\text { Copy center } \\
\text { volume }\left(\mathrm{m}^{3}\right)\end{array}$ & Ventilation & Other VOC sources & Flooring & Roof & Walls & Doors & $\begin{array}{l}\text { Other } \\
\text { furniture }\end{array}$ & $\begin{array}{l}\text { No of } \\
\text { entrances }\end{array}$ \\
\hline 1 & 1200 & $\begin{array}{l}\text { One way } \\
\text { opening }\end{array}$ & $\begin{array}{l}\text { Computer (1), Ink jet printer } \\
\text { (1) }\end{array}$ & Cement & Cement & Cement & $\begin{array}{l}\text { Front Metal } \\
\text { Shutter }\end{array}$ & Table-1, Chair-1 & 1 \\
\hline 2 & 1600 & $\begin{array}{l}\text { One way } \\
\text { opening }\end{array}$ & $\begin{array}{l}\text { Printer (1), Carpet (1), Fax } \\
\text { Machine (1), Incense (1), } \\
\text { Scanner (1), Computer (3) } \\
\text { Carpet (1) }\end{array}$ & $\begin{array}{l}\text { Cement } \\
\text { with Vinyl } \\
\text { sheet }\end{array}$ & Cement & Cement & $\begin{array}{l}\text { Front Metal } \\
\text { Shutter }\end{array}$ & $\begin{array}{l}\text { Table-2, Chair - 2, } \\
\text { Revolving } \\
\text { Chair- } 7\end{array}$ & 1 \\
\hline 3 & 960 & $\begin{array}{l}\text { 2-way } \\
\text { opening }\end{array}$ & $\begin{array}{l}\text { Computer (3), Paper cutting } \\
\text { (1), Printer (2) }\end{array}$ & Marble & $\begin{array}{l}\text { Cement, } \\
\text { Varnish }\end{array}$ & $\begin{array}{l}\text { Cement, Oil } \\
\text { painted }\end{array}$ & $\begin{array}{l}\text { Front/Back } \\
\text { Metal Shutters }\end{array}$ & $\begin{array}{l}\text { Table-1, } \\
\text { Chair - } 3\end{array}$ & 2 \\
\hline 4 & 4800 & $\begin{array}{l}\text { 3-way } \\
\text { opening }\end{array}$ & $\begin{array}{l}\text { Computer (1), Printer (1), } \\
\text { Incense (1), Binding Machine } \\
\text { (1), Photocopiers under } \\
\text { repair (3) }\end{array}$ & Mosaic & Cement & Painted & $\begin{array}{l}\text { Front Metal } \\
\text { Shutter }\end{array}$ & $\begin{array}{l}\text { Computer } \\
\text { Table-1, } \\
\text { Chair - 3, } \\
\text { Table-1 }\end{array}$ & 2 \\
\hline 5 & 4800 & $\begin{array}{l}\text { 1-way } \\
\text { opening }\end{array}$ & $\begin{array}{l}\text { Fascimile machine (1), Binding } \\
\text { Machine (1) Computer ( } 1) \text {, } \\
\text { Printer (1) Photocopiers under } \\
\text { repair (2) }\end{array}$ & Cement & Cement & Painted & $\begin{array}{l}\text { Front Metal } \\
\text { Shutter }\end{array}$ & $\begin{array}{l}\text { Computer } \\
\text { Table-2, } \\
\text { Chair - } 2\end{array}$ & 1 \\
\hline
\end{tabular}

centers for at least five years. People were invited to participate in the program by individual approach. Free blood tests and pulmonary function tests, were proposed to volunteer subjects with occupational exposure to emissions from photocopiers. All participants were actively working at the time of the study. All the subjects of the study were confined to the same geographical area to minimize interferences from ambient air pollution. All interviews, pulmonary function tests and blood collection were carried out at the photocopier centers where the subjects worked between $10.00 \mathrm{a}$.m. and 2.00 p.m. on a working day in a single visit. This study was approved by the Human Ethical Committee of Avinashilingam Institute for Home Science and Higher Education for Women, Coimbatore (HEC.2011.24). Subjects gave informed consent before data and sample collection.

\section{Selection of subjects}

Using a standardized interview schedule, personal, socio economic, professional and general health details were collected during in person interviews. Exposure to photocopiers (in terms of years of occupation at photocopier centers, average working hours/day, average working days/week), smoking histories, exposure to second hand tobacco smoke and fuels used were recorded in the interview schedule. Based on St. George's respiratory questionnaire [35], a respiratory symptoms questionnaire was also included in the interview schedule. Subjects with any known ailments like cardiovascular diseases, asthma, diabetes mellitus, hypertension, hyperthyroidism, epilepsy, etc., were excluded from the study. None of the selected subjects were on regular medications.

\section{Photocopier exposed group}

Occupational exposure was defined as minimum five years employment in a xerographic unit. Male and female operators in the age group of 20 to 60 years with at least 5 years exposure to emissions from photocopiers were included in the exposed group. Cumulative exposure to photocopiers was calculated from the number of working hours/day and number of working days/week.

Table 3 Characteristics of photocopiers and toners used in the photocopy centers

\begin{tabular}{|c|c|c|c|c|c|c|c|c|}
\hline Copy center & Business hours & Toner cake & $\begin{array}{l}\text { Toner } \\
\text { category }\end{array}$ & $\begin{array}{l}\text { Average No of } \\
\text { copies/day }\end{array}$ & $\begin{array}{l}\text { Number of } \\
\text { copy machines }\end{array}$ & $\begin{array}{l}\text { Type of copy } \\
\text { machines }\end{array}$ & $\begin{array}{l}\text { Make of copy } \\
\text { machines }\end{array}$ & Copy speed \\
\hline \multirow[t]{2}{*}{1} & 8 a.m.- 8 p.m. & ITDL & Dry, Wet & 1500 & 2 & Black (1) & Canon 3530 & $60 /$ min \\
\hline & & & & & & Colour (1) & Canon 6000 & $42 / \min$ \\
\hline \multirow[t]{2}{*}{2} & 8 a.m.- 9 p.m & CFI, ITDL & Dry, Wet & 1500 & 2 & Black (1) & Canon 3530 & $60 /$ min \\
\hline & & & & & & Colour (1) & Canon 6000 & $42 / \mathrm{min}$ \\
\hline \multirow[t]{2}{*}{3} & 8 a.m.- 10 p.m & PCS & Dry, Wet & 7000 & 4 & Black (3) & $\begin{array}{l}\text { a. IR105 (2) } \\
\text { b. Canon } 6570\end{array}$ & $\begin{array}{l}\text { a. } 105 / \mathrm{min} \\
\text { b. } 65 / \mathrm{min}\end{array}$ \\
\hline & & & & & & Colour (1) & IR 3200 & $32 / \mathrm{min}$ \\
\hline 4 & 9 a.m.- 9 p.m. & ITDL & Dry & 3000 & 2 & Black & Canon 6000 & $60 /$ min \\
\hline 5 & 8 a.m - 9 p.m. & Jet Black & Dry & 5000 & 1 & Black & IR 6060 & $60 / \mathrm{min}$ \\
\hline
\end{tabular}


Exposure was assessed by the amount of time spent in photocopier centers.

No. of hours exposed $=$ No. of working hours $/$ day $\times$ No. of working days/week $\times$ No. of years of exposure $x$ 50 weeks/year.

\section{Control group}

Healthy male and female subjects with no professional exposure to emissions from photocopiers in the age group of $20-60$ years were categorized as control group. Subjects in this group consisted of clerks, cooks, drivers, housewives, shop keepers, etc.

\section{Pulmonary function test}

Pulmonary function was assessed by using Vitalograph Alpha 6000, UK. Spirometry was performed according to the American Thoracic Society guidelines [36]. Parameters used for analysis of the flow-volume curve were forced vital capacity (FVC), forced expiratory volume in 1 second $\left(\mathrm{FEV}_{1}\right), \mathrm{FEV}_{1} / \mathrm{FVC}$ ratio, peak expiratory flow (PEF) and maximum mid expiratory flow $\left(\mathrm{FEF}_{25-75}\right)$. Results were expressed as percentages of predicted values, using equations published in 1993 by the European Respiratory Society.

\section{Analysis of biomarkers}

Peripheral venous blood samples were collected. Plasma/ serum were separated, aliquoted into labeled cryo vials and stored at $-80^{\circ} \mathrm{C}$.

Lipid peroxidation and total antioxidant capacity were measured in serum $[37,38]$. The following markers were assessed in EDTA plasma by commercial ELISA kits mentioned: $\mathrm{LTB}_{4}, 8$-Isoprostane, CRP and glutathione peroxidase - Cayman Chemical, USA; IL-8 - Koma Biotech, Korea; ICAM-1, CC-16 and ECP - USCN Life
Sciences, China. Myeloperoxidase was estimated in lithium heparin plasma by ELISA kit from Enzo Life Sciences, Switzerland. Intra-assay co-efficients of variations for the above ELISA kits varied from $1.4 \%$ to $4.0 \%$ and inter-assay co-efficients of variations were between $2.4 \%$ and $4.4 \%$.

\section{Statistical analysis}

Demographic variables were compared between the two study groups using analysis of variance (for continuous variables) and Chi-square test (for categorical variables). Odds ratio was used to assess the incidence of respiratory problems among the two groups. Differences between two groups were assessed using student's $t$ test (normal data) or Mann Whitney test (non-normal distribution). Correlations were assessed using the Spearman's rank correlation. Statistical significance was reported at two tailed $\mathrm{p}<0.05$. SPSS version 16.0 was used for statistical analysis and drawing graphs.

\section{Results}

Indoor air quality in photocopier centers

Indoor air quality was assessed in a representative sample of five photocopier centers (Table 4).

Indoor air quality in photocopier centers shows the presence of high levels of particulate matter in these work places. The levels of other air quality parameters were within permissible limits in all the units.

\section{Cohort characteristics}

Demographic data of the subjects studied are presented in Table 5. No significant differences were observed between photocopier operators and healthy control subjects in age, gender distribution or Body Mass Index (BMI).

Table 4 Indoor air quality in select photocopier centers in Coimbatore

\begin{tabular}{lcccc}
\hline Air quality parameters & Background levels $(\mathbf{n}=\mathbf{5})$ & Mean levels $(\mathbf{n}=\mathbf{5})$ & Indoor air quality & Reference levels (NAAQS, 2009) \\
\hline Carbon monoxide $(\mathrm{CO})\left(\mathrm{mg} / \mathrm{m}^{3}\right)$ & $<1.2$ & $<1.2$ & $<1.2$ & 2.0 \\
Nitrogen dioxide $\left(\mathrm{NO}_{2}\right)\left(\mu \mathrm{g} / \mathrm{m}^{3}\right)$ & $8.0 \pm 2.6$ & $8.4 \pm 3.8$ & 9.1 & 80 \\
Ozone $\left(\mathrm{O}_{3}\right)\left(\mu \mathrm{g} / \mathrm{m}^{3}\right)$ & $<9.8$ & $<9.8$ & $<9.8$ & 100 \\
Fine particulate matter $\left(\mathrm{PM}_{2.5}\right)\left(\mu \mathrm{g} / \mathrm{m}^{3}\right)$ & $128.1 \pm 21.4$ & $168.2 \pm 34.6$ & 78.5 & 60 \\
Particulate matter $\left(\mathrm{PM}_{10}\right)\left(\mu \mathrm{g} / \mathrm{m}^{3}\right)$ & $241.7 \pm 44.2$ & $376.4 \pm 63.8$ & 106.7 & 100 \\
Sulphur dioxide $\left(\mathrm{SO}_{2}\right)\left(\mu \mathrm{g} / \mathrm{m}^{3}\right)$ & $3.5 \pm 1.5$ & $4.7 \pm 2.3$ & 5.1 & 80 \\
Lead $(\mathrm{Pb})\left(\mu \mathrm{g} / \mathrm{m}^{3}\right)$ & $<0.1$ & $<0.1$ & $<0.1$ & 1.0 \\
Arsenic $(\mathrm{As})\left(\mathrm{ng} / \mathrm{m}^{3}\right)$ & $<0.1$ & $<0.1$ & $<0.1$ & 6.0 \\
Nickel $(\mathrm{Ni})\left(\mathrm{ng} / \mathrm{m}^{3}\right)$ & $<0.1$ & $<0.1$ & $<0.1$ & 20 \\
Ammonia $\left(\mathrm{NH} \mathrm{H}_{3}\right)\left(\mu \mathrm{g} / \mathrm{m}^{3}\right)$ & 2.3 & 2.5 & 2.7 & 400 \\
Benzene $\left(\mathrm{C}_{6} \mathrm{H}_{6}\right)\left(\mu \mathrm{gg} / \mathrm{m}^{3}\right)$ & $<1.0$ & $<1.0$ & $<1.0$ & 5.0 \\
Benzo $(\mathrm{a})$ pyrene $(\mathrm{BaP})\left(\mathrm{ng} / \mathrm{m}^{3}\right)$ & $<1.0$ & $<1.0$ & $<1.0$ & 1.0 \\
\hline
\end{tabular}


Table 5 Socio economic status and lifestyle of the study subjects

\begin{tabular}{llll}
\hline Demographics & Control & $\begin{array}{l}\text { Photocopier } \\
\text { workers }\end{array}$ & p value \\
\hline $\mathrm{N}$ & 43 & 81 & \\
Male (\%) & $30(70)$ & $64(79)$ & $0.253^{*}$ \\
Age Mean (S.D) & $31.7(7.4)$ & $32.6(7.1)$ & $0.467^{* *}$ \\
Monthly income(Rs) & & & \\
$\leq 3000$ & $1(2)$ & $2(3)$ & \\
$3001-10000$ & $27(63)$ & $61(75)$ & $0.047+$ \\
10000-20000 & $5(12)$ & $13(16)$ & $0.513^{* *}$ \\
$>$ 20000 & $10(23)$ & $5(6)$ & $0.041^{*}$ \\
BMI Mean (S.D) & $24.2(4.0)$ & $24.9(6.2)$ & $0.510^{* *}$ \\
Current smokers (\%) & $8(19)$ & $30(37)$ & \\
Pack years Mean (S.D) & $2.0(1.8)$ & $2.9(4.6)$ & \\
Cumulative exposure & & & 0.232 \\
(1000 s of hours) & & 13 & \\
$10-20$ & & 30 & 13 \\
$21-30$ & & $30(37)$ & \\
$31-40$ & & $11(26)$ & \\
$41-70$ & & & \\
Alcohol use & & & \\
\hline
\end{tabular}

* - Chi square test; ** - Students $t$ test; $\uparrow-$ Fisher's exact test.

$B M I$ Body mass index; Pack years $=($ Average number of cigarettes per day $/ 20) \times$ number of years smoked.

Cumulative exposure $=$ No. of working hours/day $\times$ No. of working days $/$ week $\times$ No. of years of exposure $\times 50$ weeks/year.

\section{Prevalence of respiratory symptoms and general health problems}

Prevalence of respiratory symptoms and general health problems among the subjects is presented in Figure 1. Photocopier operators reported significantly higher incidence of nasal blockage $(p=0.003)$ and breathing troubles $(\mathrm{p}=0.03)$. Excessive sputum production was also reported by a large number of photocopier operators when compared to control subjects $(\mathrm{p}=0.004)$.

\section{Lung function}

Prevalence of respiratory diseases (mild, moderate or severe restriction and/or obstruction) is presented in Table 6. High prevalence of restrictive lung disease $(28 \%$ among control group and 30\% among photocopier operators) was observed. However, no significant difference was observed between the photocopier operators and control subjects in the prevalence of respiratory diseases. A sub group analysis was carried out among non smokers of the study population. No significant difference was observed in the prevalence of lung diseases between non smoking photocopier operators and controls.

No significant difference was observed in \% predicted values of forced vital capacity (FVC), forced expiratory volume in 1 second $\left(\mathrm{FEV}_{1}\right), \mathrm{FEV}_{1} / \mathrm{FVC}$, peak expiratory flow (PEF) and maximal mid expiratory volume $\left(\mathrm{FEF}_{25-75}\right)$ between the photocopier operators and control subjects (Figure 2). Sub group analysis among non smokers did not reveal any significant difference between the two groups.

\section{Confounders and lung function}

All the subjects of the study used liquefied petroleum gas as household cooking fuel eliminating the interference of biomass fuel smoke. Cigarette smoking is a confounder in occupational exposure studies. However, lung function among smokers was not significantly different between the photocopier operators and healthy control subjects (data not shown). An interaction variable was created between pack years smoked and years of exposure. This variable did not show correlation with any of the lung function indices.

\section{Hematological status}

Table 7 shows the haematological status of the study subjects. Hematocrit, Mean Corpuscular Volume (MCV) and Red cell Distribution Width (RDW) were significantly higher among photocopier operators when compared to controls. Mixed cells (comprising eosinophils, basophils and monocytes) were significantly lower among photocopier operators than control subjects. No difference was noticed in the levels of circulating total white blood cells, lymphocytes and neutrophils between the two groups of subjects. Hematological status among non smoking photocopier operators and controls was not different from that of photocopier operators and controls. This suggests that smoking does not significantly influence hematological status in this study population.

\section{Protein levels and oxidative status}

Serum protein levels, oxidative status and inflammatory markers are shown in Table 8. No significant difference was found in serum protein levels between the two groups. However, albumin: globulin ratio was found to be significantly altered in the photocopier operators (1.1) when compared to controls (1.5).

Serum thiobarbituric acid reactive substances (TBARS) concentration was significantly higher $(\mathrm{p}<0.001)$ among the photocopier operators when compared to the controls. Serum total ferric reducing antioxidant capacity was found to be significantly lower $(p=0.001)$ among operators in photocopier centers when compared to healthy controls.

Plasma ICAM-1 ( $\mathrm{p}=0.015)$, leukotriene $\mathrm{B}_{4}$ levels $(\mathrm{p}<$ $0.001)$, ECP $(p=0.009)$ and IL-8 ( $p=0.001)$ were significantly higher in the photocopier operator group in comparison to the control group. Other inflammatory markers were not significantly different between the two groups. 


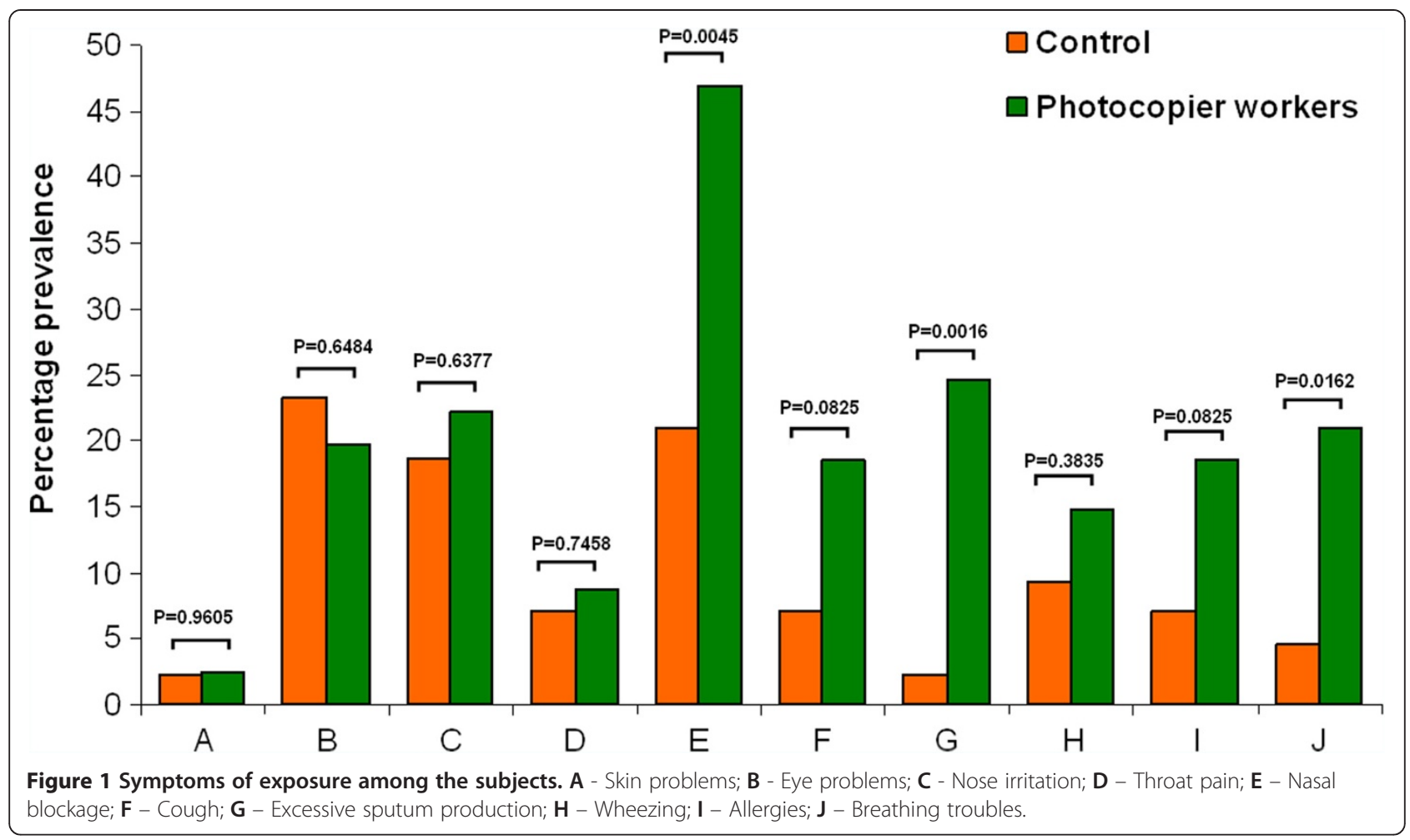

\section{Lung function and inflammatory markers}

Plasma CC-16 was found to have positive association with \% predicted FVC $(\mathrm{r}=0.195, \mathrm{p}=0.04)$. Plasma CRP levels were also found to have a negative correlation with \% predicted FVC $(\mathrm{r}=-0.261, \mathrm{p}=0.005)$ and \% predicted $\mathrm{FEV}_{1}(\mathrm{r}=-0.221, \mathrm{p}=0.019)$. No significant relationship was found between lung function and other inflammatory biomarkers.

\section{Smoking status and inflammatory biomarkers}

Smoking status was found to have a positive correlation with plasma levels of CC-16 $(r=0.167, p=0.033)$. Interaction between smoking and cumulative hours of exposure was studied on the inflammatory markers. This interaction was not found to alter the effects of photocopier exposure on the different markers assessed. Among non smokers, levels of inflammatory markers were similar to that observed in the combined group suggesting no appreciable influence of smoking.

\section{Discussion}

Ambient air quality in photocopier centers has not been previously reported in India. Levels of $\mathrm{PM}_{2.5}$ and $\mathrm{PM}_{10}$ were about 2-3 fold higher than the permissible limits during working hours. Even background $\mathrm{PM}_{2.5}$ and $\mathrm{PM}_{10}$ levels were higher than the permissible levels. Similar results have been reported by many investigators around the world over the last decade [39-47]. Emissions of nanoparticles from photocopiers have also been recently reported [48]. Long term exposure to particulate matter has been associated with cardiovascular disease by the mechanisms of systemic inflammation, direct and indirect coagulation activation and direct translocation into systemic circulation. Respiratory diseases are also exacerbated by exposure to PM by creating oxidative stress and inflammation [49-51].

The levels of other ambient air quality parameters such as carbon monoxide, nitrogen dioxide, ozone, sulphur dioxide, lead, arsenic, nickel and ammonia. Benzene and benzo(a)pyrene were also within permissible levels. The

Table 6 Prevalence of lung diseases

\begin{tabular}{lcccccc}
\hline Groups & Control $\mathbf{n}(\%)$ & Photocopier operators $\mathbf{n}(\%)$ & $\mathbf{p}$ value & Photocopiers $\mathbf{n}=\mathbf{4 6}$ & Control $\mathbf{n}=\mathbf{2 9}$ & $\mathbf{p}$ value \\
\hline Restriction & $12(28)$ & $24(30)$ & 0.841 & $5(11)$ & $3(10)$ & 0.766 \\
Obstruction & $4(9)$ & $8(10)$ & 0.918 & $12(26)$ & $10(35)$ & 0.305 \\
Restriction \& obstruction & $2(5)$ & $4(5)$ & 0.967 & $4(9)$ & $2(7)$ & 0.780 \\
\hline
\end{tabular}

$\mathrm{p}$ values for Chi Square test. 


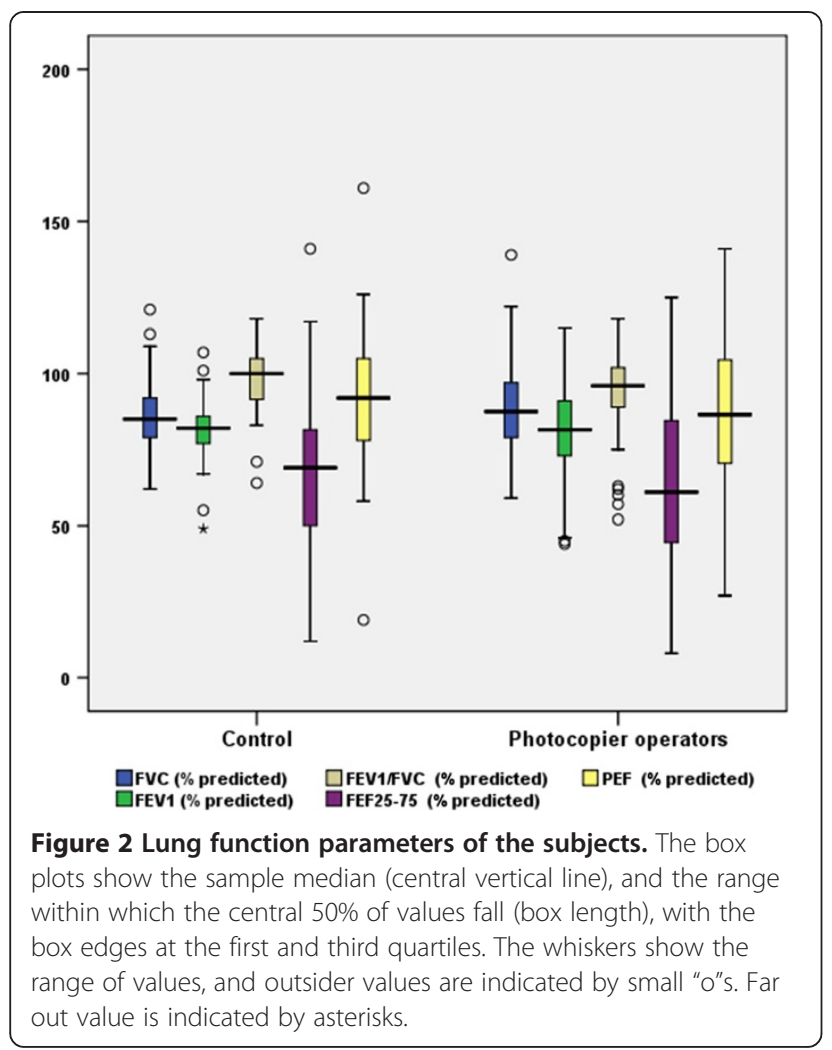

Table 7 Hematological parameters

\begin{tabular}{|c|c|c|c|c|c|c|}
\hline \multirow[t]{2}{*}{ Marker } & \multirow[t]{2}{*}{ Control $n=43$} & \multirow{2}{*}{$\begin{array}{c}\text { Photocopier } \\
\text { operators } n=81\end{array}$} & \multirow[t]{2}{*}{$p$ value } & \multicolumn{3}{|c|}{ Non smokers } \\
\hline & & & & Control $n=29$ & $\begin{array}{c}\text { Photocopier } \\
\text { operators } n=46\end{array}$ & $p$ value \\
\hline$\overline{W B C}\left(10^{3} / \mu \mathrm{L}\right)$ & $7.1(5.8-8.2)$ & $6.6(5.6-7.7)$ & 0.216 & $7.1(5.5-8.9)$ & $7.0(5.4-8.2)$ & 0.358 \\
\hline $\mathrm{RBC}\left(10^{6} / \mu \mathrm{L}\right)$ & $5.1(4.6-5.8)$ & $5.5(4.9-6.0)$ & 0.082 & $5.0(4.4-5.5)$ & $5.6(4.7-6.1)$ & 0.028 \\
\hline Hemoglobin (g/dL) & $15.1(12.1-16.6)$ & $16.0(13.9-17.0)$ & 0.085 & $13.5(11.5-15.9)$ & $15.5(13.3-16.6)$ & 0.065 \\
\hline Hematocrit (\%) & $44.1(37.4-48.0)$ & $46.9(43.8-50.2)$ & 0.015 & $39.5(35.5-45.6)$ & $45.4(38.4-49.0)$ & 0.017 \\
\hline$M C V(f L)$ & $84.0(79.6-87.8)$ & $88.4(83.5-91.8)$ & 0.002 & $83.1(75.9-86.7)$ & $85.3(80.9-90.5)$ & 0.047 \\
\hline $\mathrm{MCH}(\mathrm{pg})$ & $28.7(25.6-30.5)$ & $29.3(27.8-31.6)$ & 0.064 & $28.5(24.2-30.4)$ & $28.7(26.8-30.5)$ & 0.485 \\
\hline $\mathrm{MCHC}(\mathrm{g} / \mathrm{dL})$ & $34.0(32.5-35.5)$ & $33.8(32.0-35.0)$ & 0.730 & $34.0(31.9-35.8)$ & $33.6(31.3-34.9)$ & 0.474 \\
\hline Platelets $\left(10^{3} / \mu \mathrm{L}\right)$ & $255(221-315)$ & $267(221-303)$ & 0.914 & $281(226-318)$ & $259(210-316)$ & 0.334 \\
\hline Lymphocytes $\left(10^{3} / \mu \mathrm{L}\right)$ & $2.2(1.9-3.0)$ & $2.3(1.9-2.6)$ & 0.713 & $2.2(1.8-2.9)$ & $2.4(1.9-2.7)$ & 0.830 \\
\hline Neutrophils $\left(10^{3} / \mu \mathrm{L}\right)$ & $3.7(2.9-4.5)$ & $3.7(3.1-4.8)$ & 0.928 & $3.9(3.3-5.8)$ & $4.0(3.4-5.1)$ & 0.694 \\
\hline Mixed cells $\left(10^{3} / \mu \mathrm{L}\right)$ & $0.8(0.7-1.1)$ & $0.7(0.5-0.9)$ & 0.004 & $0.8(0.6-1.0)$ & $0.7(0.5-0.9)$ & 0.062 \\
\hline RDW (fL) & $42.7(40.9-44.4)$ & $44.5(42.5-47.0)$ & $<0.001$ & $42.4(40.8-43.5)$ & $44.1(46.5)$ & 0.006 \\
\hline PDW (fL) & $12.3(11.3-13.9)$ & $12.1(11.3-13.2)$ & 0.829 & $12.2(11.2-13.9)$ & $12.4(11.6-13.1)$ & 0.693 \\
\hline MPV (fL) & $9.8(9.4-10.7)$ & $9.9(9.4-10.4)$ & 0.920 & $9.8(9.4-10.5)$ & $10.1(9.7-10.4)$ & 0.271 \\
\hline PLCR (\%) & $23.9(20.1-29.6)$ & $25.0(19.8-28.5)$ & 0.944 & $23.3(20.0-28.9)$ & $26.5(23.0-28.1)$ & 0.274 \\
\hline
\end{tabular}

RBC Red blood cells, MCV Mean corpuscular volume, MCH Mean corpuscular hemoglobin, MCHC Mean corpuscular hemoglobin concentration, RDW Red cell distribution width, PDW Platelet distribution width, MPV Mean platelet volume, PLCR Platelet large cell ratio, $\mu L$ Microlitre, $d L$ Deciliter, $f L$ (femtolitre), pg (picogram), p value for Mann Whitney test. levels of benzene, benzo(a)pyrene were also within limits in spite of the presence of many VOC sources in these photocopy centers. Previous studies [52-54], also found styrene were below the occupational exposure threshold guidelines in photocopier centers. All the photocopier centers included were open air buildings where one wall was replaced by retractable shutters, open for ventilation throughout the business hours. In spite of the improved air circulation in the photocopier centers, the very high levels of particulate matter in these centers are an area of concern.

Photocopier operators have a high prevalence of respiratory problems such as nasal blockage, breathing troubles and excessive sputum production when compared to control subjects. This might be due to the high particulate matter exposure. Particulate matter might contribute to increased respiratory symptoms and chronic nasal and paranasal sinus problems $[55,56]$.

This is the first study on lung function in photocopier operators. The photocopier operators assessed in the present study worked with imported second hand copiers, which have been, since, banned in India.

The high prevalence of restrictive lung diseases among the both the groups of subjects could not be explained in the context of the present study. No data is available on the prevalence of lung diseases in this geographical area/ ethnic group to compare the data. A larger population that benzene, toluene, ethylbenzene, xylenes (BTEXS) and 
Table 8 Markers of oxidative-inflammatory status

\begin{tabular}{|c|c|c|c|c|c|c|}
\hline \multirow[t]{2}{*}{ Marker } & \multirow[t]{2}{*}{ Control $n=43$} & \multirow{2}{*}{$\begin{array}{c}\text { Photocopier } \\
\text { operators } n=81\end{array}$} & \multirow[t]{2}{*}{$p$ value } & \multicolumn{3}{|c|}{ Non smokers } \\
\hline & & & & Control $n=29$ & $\begin{array}{c}\text { Photocopier } \\
\text { operators } n=46\end{array}$ & $p$ value \\
\hline Total protein $(\mathrm{g} / \mathrm{L})$ & $68.9(63.0-76.3)$ & $72.4(66.1-75.3)$ & 0.167 & $68(60.1-73.0)$ & $72(67.7-74.8)$ & 0.048 \\
\hline Albumin (g/L) & $39.6(36.7-44.9)$ & $37.1(33.1-40.9)$ & 0.011 & $38.8(34.6-42.3)$ & $36.5(32.9-41.0)$ & 0.228 \\
\hline Globulin (g/L) & $27.1(20.4-35.8)$ & $34.0(28.6-39.4)$ & 0.015 & $27.9(20.4-35.5)$ & $34.0(29.0-39.3)$ & 0.042 \\
\hline FRAC (mM) & $1.5(0.8-1.9)$ & $1.0(0.8-1.4)$ & 0.010 & $1.6(0.8-2.0)$ & $1.0(0.7-1.4)$ & 0.008 \\
\hline TBARS $(\mu \mathrm{M})$ & $1.4(1.0-1.9)$ & $2.7(2.1-3.5)$ & $<0.001$ & $1.4(0.8-1.7)$ & $2.8(2.1-3.4)$ & $<0.001$ \\
\hline 8-Isoprostane (pg/mL) & $41.7(23.6-52.8)$ & $46.4(31.7-65.4)$ & 0.146 & $35.4(20.5-51.5)$ & $45.5(24.6-67.5)$ & 0.159 \\
\hline CRP $(\mu \mathrm{g} / \mathrm{mL})$ & $1.4(0.6-2.6)$ & $0.9(0.4-1.8)$ & 0.083 & $1.7(1.0-2.8)$ & $1.0(0.4-2.0)$ & 0.051 \\
\hline ICAM-1 (ng/mL) & $113(97-165)$ & $187(104-266)$ & 0.015 & $113(99-165)$ & $135(101-239)$ & 0.356 \\
\hline $\mathrm{LTB}_{4}(\mathrm{ng} / \mathrm{mL})$ & $13.0(7.6-40.1)$ & $81.9(22.3-159.1)$ & $<0.001$ & $9.2(6.5-15.9)$ & $78(12-169)$ & $<0.001$ \\
\hline CC-16 (ng/mL) & $7.3(2.7-28.3)$ & $7.8(3.3-33.8)$ & 0.705 & $7.8(2.7-36.1)$ & $7.1(2.9-32.3)$ & 0.908 \\
\hline $\mathrm{ECP}(\mathrm{ng} / \mathrm{mL})$ & $135(80-207)$ & $213(118-307)$ & 0.009 & $128(80-207)$ & $215(147-327)$ & 0.015 \\
\hline IL-8 (pg/mL) & $17.4(10.6-18.6)$ & $18.1(17.1-20.7)$ & 0.001 & $16.4(8.6-17.8)$ & $18.2(16.7-21.1)$ & 0.002 \\
\hline
\end{tabular}

FRAC Ferric Reducing Antioxidant Capacity, TBARS Thiobarbituric acid reactive substances, CRP C-reactive protein, ICAM-1 Intercellular Adhesion Molecule 1, Leukotriene $\mathrm{B}_{4}$ - Leukotriene B4, CC-16, Clara cell protein, ECP Eosinophilic Cationic Protein, IL-8 Interleukin 8, pg Picogram, $\mu \mathrm{g}$ Microgram, $n g$ Nanograms, $m M$ Millimoles, $\mu M$ Micromoles, $\mathrm{p}$ values for Mann Whitney test.

study might throw light on the causes for this high prevalence.

Lung function parameters did not show any significant differences between the photocopier operators and healthy control groups. Studies on pulmonary function among operators in toner manufacturing units in Japan also reported similar results $[2,22,23]$.

In the present study, the percentage of smokers was significantly higher among photocopier operators group when compared to controls. However, smoking status did not significantly influence lung function and inflammation of the photocopier operators and control subjects. This might be due to the very few pack years smoked between the cohorts.

Hematocrit is the volume of red blood cells expressed as a percentage of a given volume of whole blood. Higher levels of hematocrit, were associated with an increased risk of developing heart failure in a long-term follow-up study [57]. The high levels of hematocrit among photocopier operators also signify increased cardiovascular risk which is rational considering the high particulate matter exposure.

Red blood cell distribution width (RDW) is a numerical measure of the size variability of circulating erythrocytes and is routinely reported as a component of complete blood count in the differential diagnosis of anemia. RDW has been recently reported to be a strong and independent predictor of adverse outcomes in the general population $[58,59]$. High RDW might also reflect a general inflammatory state causing ineffective erythropoiesis in addition to vascular disease progression [60]. High RDW among the photocopier operators may be due to chronic photocopier exposure and reflect their inflammatory state.

Mixed cells comprising of eosinophils, basophils and monocytes were significantly lower among the photocopier operators. All these cells are involved in the inflammatory response to tissue injury. The significant decrease in mixed cell population might be due to the migration of these cells to the airways, the site of injury caused by chronic exposure to pollutants. A decrease in circulating monocytes and increase in migration of monocytes to inflammatory sites upon exposure to ambient air pollution have been observed by earlier studies [61].

Albumin levels were significantly reduced in photocopier operators suggesting inflammation. When albumin concentration is reduced, other risk factors associated with both inflammation and cardiovascular risk is increased [62]. An increase in serum globulin levels may be reflective of a mild systemic immune response [63]. In the present study, significantly decreased albumin and increased globulin among photocopier operators might be caused by inflammation and systemic immune response.

Oxidative stress followed by inflammation is thought to be central in the mechanisms of action for the health effects of PM [64]. Serum TBARS was significantly increased in the photocopier operators when compared to the unexposed controls. This is in tune with the high serum TBARS among photocopier operators already reported [13]. However, levels of 8-Isoprostane did not show significant differences between the two groups. TBARS may be a more sensitive biomarker than 8- 
isoprostane and may be a useful tool for investigating air pollution-related oxidative stress as discussed by [65].

In harmony with the above results, total serum ferric reducing antioxidant capacity was significantly reduced among the photocopier operators when compared to the healthy control group suggesting increased oxidative stress. The results of this study show that exposure to emissions from photocopiers on a regular basis causes oxidative stress analogous to the effects of several air pollutants, diesel exhaust and cigarette smoke [66-68].

The lack of significant increase in CRP levels among photocopier workers when compared to control is mystifying, given the significant rise in other inflammatory markers. The insignificant increase in CRP levels among photocopier workers may be in view of the fact that particulate matter is the primary pollutants emitted by photocopiers. No consistent rise has been observed in CRP levels after exposure to particulate matter [69].

CRP levels have been strongly and independently associated with lung function by quite a few studies over the years [70-72]. In concurrence, in the present study, C Reactive Protein was found to be the best indicator of pulmonary function among the inflammatory markers assayed in the present study. Significant negative correlations with percent predicted FVC and $\mathrm{FEV}_{1}$ were observed. The lack of elevation in CRP was in accordance with the lack of lung function impairment.

Intercellular adhesion molecule (ICAM)- 1 is a cell adhesion molecule expressed by several cells including leukocytes and endothelial cells. Soluble ICAM-1 (sICAM-1) is a form of ICAM-1 found in plasma. sICAM-1 levels are elevated in cardiovascular diseases, autoimmune disorders, cancer and acute lung injury $[73,74]$. Concentration of sICAM-1 is an indicator of coronary heart disease [75]. The significant increase in plasma ICAM-1 of photocopier operators may be related to systemic inflammation caused by exposure to emissions from photocopiers on a routine basis.

Significant rise in leukotriene $B_{4}$ levels of the photocopier exposed subjects in the present study is suggestive of inflammation. Further, $\mathrm{LTB}_{4}$ has also been associated with the progression of atherosclerosis. The main effect of the pro-inflammatory eicosanoid leukotriene $\mathrm{B}_{4}$ is related to the inflammatory response and it facilitates capillary extravasation and a maintained immune activation within the atherosclerotic lesions [76,77].

Clara cells can modulate immune responses by secretion of both pro- and anti-inflammatory factors. CC-16 is a natural immune-regulator protecting the respiratory tract from unwanted inflammatory reactions [78]. CC-16 levels in serum increase when lung epithelium permeability is adversely affected by air pollutants or other lung toxicants. On the contrary, reduced levels of CC-16 in lung lavage fluid occur in several lung disorders, probably due to a decrease in the production of $\mathrm{CC}-16$ as a consequence of a depletion of Clara cells [79]. In the present study, neither significant increase nor significant decrease was observed in the plasma levels of CC-16 of photocopier operators indicating insignificant effects of the PM on the lung epithelium which is surprising. However, changes in CC-16 and CRP levels were not observed after in traffic exposure to $\mathrm{PM}_{2.5}$ and $\mathrm{PM}_{10}$ [80].

ECP is the best known of the eosinophil proteins, assessed and used extensively. It is transported and stored in the mature eosinophil granules at a high rate. The majority of ECP is released after the cell has left the circulation. Several types of inflammatory stimulations have been shown to cause eosinophil degranulation [81]. In the present study, elevation of plasma ICAM-1 and $\mathrm{LTB}_{4}$ observed in the photocopier exposed subjects, might have contributed to the elevated levels of plasma ECP in the subjects. This provides further evidence of inflammation due to exposure to emissions from photocopiers.

IL-8, a proinflammatory cytokine, was also significantly higher among photocopier operators $[82,83]$. Increased serum levels of IL-8 are correlated with an increased risk of cardiovascular disease or acute cardiovascular events [84]. Thus, in the present study, high plasma IL-8 levels signify inflammation among photocopier operators.

Oxidative stress and inflammation are strongly connected and either one can lead to the other. It is likely that the pro-oxidant potential of ambient particles determine their ability to activate pathways that lead to prooxidant and pro-inflammatory effects in the vasculature and promotion of atherosclerosis [85]. Chronic exposure to emissions from photocopiers may lead to similar consequences, due to the chronic particulate matter exposure in these units.

\section{Conclusions}

Long term exposure to emissions from photocopiers was not associated with decreased lung function. However, photocopier exposure was associated with high oxidative stress and inflammation, leading to higher risk of atherosclerosis and cardiovascular diseases.

\section{Abbreviations}

8 IP: 8-Isoprostane; CC-16: Clara cell protein; CRP: C reactive protein; ECP: Eosinophilic cationic protein; ELISA: Enzyme linked immunosorbent assay; FRAC: Ferric reducing antioxidant capacity; FVC: Forced vital capacity; $\mathrm{FEV}_{1}$ : Forced expiratory volume in 1 second; ICAM-1: Inter cellular adhesion molecule 1; IL-8: Interleukin 8; LTB 4 : Leukotriene $B_{4}$; TBARS: Thio barbituric acid reactive substances.

\section{Competing interests}

The authors have not over the past three years had any financial relations with organizations that might have an interest in the submitted work. The authors hereby declare no relationships or activities that could appear to have influenced the submitted work. 


\section{Authors' contributions}

$\mathrm{NE}$ conceptualized and designed the experiments, recruited majority of the subjects, carried out pulmonary function tests, conducted majority of experiments, analyzed the data, performed statistical analysis and took the lead on writing the manuscript. VK collected samples, carried out experiments, helped in interpretation of results and revising the manuscript. BV contributed to manuscript preparation. All authors read and approved the final manuscript. JGP contributed to the design of the study, supervised the study and helped with revising the manuscript.

\section{Acknowledgements}

This work was supported by the Department of Science and Technology, Government of India - Women Scientist Fellowship (WOS-A/LS 188/2009) and Indian Council of Medical Research (No. 5/8/4-10/Env/2009-NCD-1), Government of India. We gratefully acknowledge the technical assistance provided by Mrs. Shanthi Ananth, Field Assistant, ICMR project in collecting blood samples from the subjects. We are grateful to the subjects who participated in the study.

Received: 18 March 2013 Accepted: 30 August 2013

Published: 11 September 2013

\section{References}

1. Global Industry Analysts. http://www.reportlinker.com/p092541/WorldPrinting-Machinery-Supplies-Market.html, 2.

2. Yang CY, Huang YC: A cross sectional study of respiratory and irritant health symptoms in photocopier operators in Taiwan. J Toxicol Env Health Part A 2008, 71:1314-1317.

3. Pirela S, Cohen J, Molina R, Brain J, Bello D, Demokritou P: Effects of copier emitted nanoparticles on the lung physiology: an in vivo toxicological characterization. In American Association for Aerosol Research 30th Annual Conference. California American Association for Aerosol Research; 2011:103. Abstract No.814.

4. Khatri M, Bello D, Gaines P, Martin J, Pal AK, Gore R, Woskie S: Nanoparticles from photocopiers induce oxidative stress and upper respiratory tract inflammation in healthy volunteers. Nanotoxicology. in press.

5. Gallardo M, Romero P, Sanchezquevedo MC, Lopezcaballero JJ: Siderosilicosis due to photocopier toner dust. Lancet 1994, 344:412-413.

6. Ambruster C, Dekan G, Hovorka A: Granulomatous pneumonitis and mediastinal lymphadenopathy due to photocopier toner dust. Lancet 1996, 348:690.

7. Jaakkola MS, Yang LY, Leromnimon A, Jaakkola JJK: Office work, SBS and respiratory and sick building syndrome symptoms. Occup Environ Med 2007, 64:178-184.

8. Rybicki BA, Amend KL, Maliarik MJ, lanuzzi MC: Photocopier exposure and risk of sarcoidosis in African-American sibs. Sarcoidosis Vasc Diffuse Lung Dis 2004, 21:49-55.

9. Chang SU, Zheng SHU, Jiang-Wdi YE: Investigation of sick building syndrome (SBS) and related risk factors in people working in office environment. J Env Health 2010, 03:24.

10. Goud KI, Shankar B, Vijayashree B, Ahuja YR: DNA damage and repair studies in individuals working with photocopying machines. Int J Hum Genet 2001, 1:139-143.

11. Gadhia PK, Patel D, Solanki KB, Tamakuwala DN, Pithawala MA: A preliminary cytogenetic and haematological study of photocopying machine operators. Ind J Occup Environ Med 2005, 9:22-25.

12. Manikandan P, Balachandar V, Sasikala K, Mohanadevi S, Lakshmankumar B: DNA damage in operators occupationally exposed to photocopying machines in Coimbatore, South India, using comet assay. Internet J Toxicol 2010, 7:1-9.

13. Kleinsorge EC, Erben M, Galan MG, Barison C, Gonsebatt ME, Simoniello MF: Assessment of oxidative status and genotoxicity in photocopier operators: a pilot study. Biomarkers 2011, 16:642-648.

14. Gminski R, Decker K, Heinz C, Seidel A, Konczol M, Goldenberg E, Grobèty B, Ebner W, Gierè R, Mersch-Sundermann V: Genotoxic effects of three selected black toner powders and their dimethyl sulfoxide extracts in cultured human epithelial A549 lung cells in vitro. Environ Mol Mutagen 2011, 52:296-309.

15. Furukawa $Y$, Aizawa $Y$, Okada M, Watanabe M, Niitsuya M, Kotani M: Negative effect of photocopier toner on alveolar macrophages determined by in vitro magnetometric evaluation. Ind Health 2002, 40:214-221.

16. Morimoto $Y$, Hirohashi M, Kasai T, Oyabu T, Ogami A, Myojo T, Murakami M, Nishi K, Kadoya C, Todoroki M, Yamamoto M, Kawai K, Kasai H, Tanaka I: Effect of polymerized toner on rat lung in chronic inhalation study. Inhal Toxicol 2009, 21:809-905.

17. Möller A, Muhle H, Creutzenberg O, Bruch J, Rehn B, Blome H, Möller A, Muhle $\mathrm{H}$, Creutzenberg O, Bruch J, Rehn B, Blome H: Biological procedures for the toxicological assessment of toner dusts. Gefahrstoffe-Reinhaltung der Luft 2004, 64:13-31.

18. Pott F, Roller M: Carcinogenicity study with nineteen granular dusts in rats. Eur J Oncol 2005, 10:249-281.

19. Mohr U, Ernst H, Roller M, Pott F: Pulmonary tumor types induced in Wistar rats of the so-called "19-dust study". Exp Toxicol Pathol 2006, 58:13-20.

20. Theegarten D, Boukercha S, Philppou S, Anhenn O: Submesothelial deposition of carbon nanoparticles after toner exposition: case report. Diagn Pathol 2010, 5:77.

21. Nakadate T, Yamano Y, Adachi C, Kikuchi Y, Nishiwaki Y, Nohara M, Satoh T, Omae K: A cross sectional study of the respiratory health of workers handling printing toner dust. Occup Environ Med 2006, 63:244-249.

22. Kitamura H, Terunuma N, Kurosaki S, Hata K, Ide R, Kuga H, Kakiuchi N, Masuda M, Totsuzaki T, Osata A, Uchino B, Kitahara K, Iwasaki A, Yoshizumi K, Morimoto Y, Kasai H, Murase T, Higashi T: Cross sectional study on respiratory effect of toner exposed work in manufacturing plants, Japan: pulmonary function, blood cells, and biochemical markers. Hum Exp Toxicol 2009, 28:331-338.

23. Terunuma N, Kurosaki S, Kitamura H, Hata K, Ide R, Kuga H, Kakiuchi N, Masuda M, Totsuzaki T, Osata A, Uchino B, Kitahara K, Iwasaki A Yoshizumi K, Morimoto Y, Kasai H, Murase T, Higashi T: Cross sectional study on respiratory effect of toner exposure. Hum Exp Toxicol 2009, 28:325-330.

24. Is 5182. Available at https://law.resource.org/pub/in/bis/.

25. BIS method IS 5182 part 10; 2009. https://law.resource.org/pub/in/bis/S02/ is.5182.10.1999.pdf.

26. BIS method IS 5182 part 6; 2006. https://law.resource.org/pub/in/bis/S02/ is.5182.06.2006.pdf.

27. Lodge JP: Methods of air sampling and analysis. 3rd edition. Florida: Lewis Publishers; 1988.

28. BIS method IS 5182 part 9; 2009. https://law.resource.org/pub/in/bis/S02/ is.5182.09.1974.pdf.

29. BIS method IS 5182 part 4; 2005. https://law.resource.org/pub/in/bis/S02/ is.5182.04.1999.pdf

30. BIS method IS 5182 part 23; 2012. https://law.resource.org/pub/in/bis/S02/ is.5182.23.2006.pdf.

31. BIS method IS 5182 part 2; 2001. https://law.resource.org/pub/in/bis/S02/ is.5182.02.2001.pdf.

32. USEPA 10 compendium 3.5. www.epa.gov/ttnamti1/files/ambient/inorganic/ iocompen.pdf.

33. BIS method IS 5182 part 12; 2004. https://law.resource.org/pub/in/bis/S02/ is.5182.12.2004.pdf.

34. USEPA method TO -13. http://www.epa.gov/ttnamti1/files/ambient/airtox/to13arr.pdf.

35. Jones PW, Quirk FH, Baveystock CM: The St. George's respiratory questionnaire. Respir Med 1991, 85:25-31.

36. Miller MR, Crapo R, Hankinson J, Brusasco V, Burgos F, Casaburi R, Coates A Enright P, van der Grinten CPM, Gustafsson P, Jensen R, Johnson DC, MacIntyre N, McKay R, Navajas D, Pedersen OF, Pellegrino R, Viegi G, Wanger J: General considerations for lung function testing. Series ATS/ ERS Task Force: standardisation of lung function testing, Edited by Brusasco, Crapo R, Viegi G. Eur Respir J 2005, 26:153-161.

37. Jentzsch AM, Bachmann H, Furst P, Biesalski HK: Improved analysis of malondialdehyde in human body fluids. Free Radical Bio Med 1996, 20:251-256

38. Benzie IFF, Strain JJ: The ferric reducing ability of plasma (FRAP) as a measure of "antioxidant" power: the FRAP assay. Anal Biochem 1996, 239:70-76.

39. Kagi N, Fujii S, Horiba Y, Namiki N, Ohtani Y, Emi H, Tamura H, Kim YS: Indoor air quality for chemical and ultrafine particle contaminants from printers. Build Environ 2007, 42:1949-1954.

40. Lee CW, Hsu DJ: Measurements of fine and ultrafine particles formation in photocopy centers in Taiwan. Atmos Environ 2007, 41:6598-6609. 
41. Wensing $M$, Schripp $T$, Unde $E$, Salthammer T: Ultra-fine particles release from hardcopy devices: sources, real-room measurements and efficiency of filter accessories. Sci Total Environ 2008, 407:418-427.

42. Adetunji H, Pinto LMM, Siddique A, Samuel S: Potential occupational health risk from exposure to nanoscale particles from photocopiers - a pilot study. Revue Internationale sur I'Ingenierie des Risques Industriels 2009, 2:15-27.

43. Morawska L, He C, Johnson G, Jayaratne R, Salthammer T, Wang H, Uhde $E_{\text {, }}$ Bostrom T, Modini R, Ayoko G, McGarry P, Wensing M: An investigation into the characteristics and formation mechanisms of particles originating from the operation of laser printers. Environ Sci Technol 2009, 43:1015-1022

44. Schripp T, Mulakampilly SJ, Delius W, Uhde E, Wensing M, Salthammer T, Kreuzig R, Bahadir M, Wang L, Morawska L: Comparison of ultrafine particle release from hardcopy devices in emission test chambers and office rooms. Gefahrstoffe - Reinhaltung der Luft 2009, 69:71-76.

45. He C, Morawska L, Wang H, Jayaratne R, McGarry PD, Johnson GR, Bostrom TE, Gonthier J, Authemayou S, Ayoko GA: Quantification of the relationship between fuser roller temperature and laser printer emissions. J Aerosol Sci 2010, 41:523-530.

46. McGarry $\mathrm{P}$, Morawska L, He C, Jayaratne R, Falk M, Tran Q, Wang H: Exposure to particles from laser printers operating within office workplaces. Environ Sci Tech 2011, 45:6444-6452.

47. Tang T, Hurra $\beta$ J, Gminski R, Mersch-Sundermann V: Fine and ultrafine particles emitted from laser printers as indoor air contaminants in German offices. Environ Sci Poll Res 2011. doi:10.1007/s11356-011-0647-5.

48. Bello D, Martin J, Santeufemio C, Sun Q, Bunker KL, Shafer M, Demokritou P: Physicochemical and morphological characterization of nanoparticles from photocopiers: implications for environmental health. Nanotoxicol. in press.

49. Anderson JO, Thundiyil JG: Clearing the air: a review of the effects of particulate matter air pollution on human health. J Med Toxicol 2012, 8:166-175

50. Peters A, Dockery DW, Muller JE, Mittleman MA: Increased particulate air pollution and the triggering of myocardial infarction. Circulation 2001, 103:2180-2185.

51. Riedider M, Cascio WE, Grigges TR, Herbst MC, Bromberg PA, Neas L, Williams RW, Devlin RB: Particulate matter exposure in cars is associated with cardiovascular effects in healthy young men. Am J Respir Crit Care Med 2004, 169:934-940.

52. Ewers U, Nowak D: Health hazards caused by laser printers and copiers. Gefahrstoffe - Reinhaltung der Luft 2006, 66:203-210.

53. Sarkhosh M, Mahvi AH, Zare MR, Fakhri Y, Shamsolahi HR: Indoor contaminants from hardcopy devices: characteristics of VOCs in photocopy centers. Atmos Environ 2012, 63:307-312.

54. Lee CW, Dai YT, Chien CH, Hsu DJ: Characteristics and health impacts of volatile organic compounds in photocopy centers. Environ Res 2006, 100:139-149.

55. Riechelmann $H$, Rettinger $G$, Weschta $M$, Keck $T$, Deutschle $T$ : Effects of low toxicity particulate matter on human nasal function. $J$ Occup Environ Med 2003, 45:54-60.

56. Swiston JR, Davidson W, Attridge S, Li GT, Brauer M, van Eeden SF: Wood smoke exposure induces a pulmonary and systemic inflammatory response in firefighters. Eur Respir J 2008, 32:129-138.

57. Coglianese EE, Qureshi MM, Vasan RS, Wang TJ, Moore LL: Usefulness of the blood hematocrit level to predict heart failure in a community. Am J Cardiol 2012, 109:241-245.

58. Perlstein TS, Weuve J, Pfeffer MA, Beckman JA: Red blood cell distribution width and mortality risk in a community-based prospective cohort. Arch Intern Med 2009, 169:588-594.

59. Patel KV, Semba RD, Ferrucci L, Newman AB, Fried LP, Wallace RB, Bandinelli S, Phillips CS, Yu B, Connelly S, Shlipak MG, Chaves PH, Launer LJ, Ershler WB, Harris TB, Longo DL, Guralnik JM: Red cell distribution width and mortality in older adults: a meta-analysis. J Gerontol A Biol Sci Med Sci 2010, 65:258-65.

60. Felker GM, Allen LA, Pocock SJ, Shaw LK, McMurray JJV, Pfeffer MA, Swedberg K, Wang D, Yusuf S, Michelson WL, Granger CB: Red cell distribution width as a novel prognostic marker in heart failure. J Am Coll Cardiol 2007, 50:40-47.

61. Yatera K, Hsieh J, Hogg JC, Tranfield E, Suzuki H, Shih C-H, Behzad AR, Vincent $R$, Van Eeden SF: Particulate matter air pollution exposure promotes recruitment of monocytes into atherosclerotic plaques. Am J Physiol - Heart Circ Physiol 2008, 294:H944-H953.

62. Don BR, Kaysen G: Serum albumin: relationship to inflammation and nutrition. Semin Dial 2004, 17:432-7.

63. OToole TE, Hellman J, Wheat L, Haberzettl P, Lee J, Conklin DJ, Bhatnagar A, Pope CA: Episodic exposure to fine particulate air pollution decreases circulating levels of endothelial progenitor cells. Circ Res 2010 107:200-203.

64. Möller P, Loft S: Oxidative damage to DNA and lipids as biomarkers of exposure to air pollution. Environ Health Perspect 2010, 118:1126-1136.

65. Liu L, Poon R, Chen L, Frescura AM, Montuschi P, Ciabattoni G, Wheeler A, Dales R: Acute effects of air pollution on pulmonary function, airway inflammation and oxidative stress in asthmatic children. Environ Health Perspect 2009, 117:668-674.

66. Valavanidis A, Fiotakis K, Vlachogianni T: The role of stable free radicals, metals and PAHs of airborne particulate matter in mechanisms of oxidative stress and carcinogenicity. In Urban Airborne Particulate Matter, Environmental Science and Engineering. Edited by Zereini F, Wiseman CLS. Berlin: Springer; 2010:411-412.

67. Araujo JA, Barajas B, Kleinman M, Wang X, Bennett BJ, Gong KW, Navab M, Harkema J, Sioutas C, Lusis AJ, Nel AE: Ambient particulate pollutants in the ultrafine range promote early atherosclerosis and systemic oxidative stress. Circ Res 2008, 108:589-596.

68. Romieu I, Castro-Giner F, Kunzli N, Sunyer J: Air pollution, oxidative stress and dietary supplementation: a review. Eur Respir J 2008, 31:179-197.

69. Li Y, Rittenhouse-Olson K, Scheider WL, Mu L: Effect of particulate matter air pollution on C-reactive protein: a review of epidemiologic studies. Rev Environ Health 2012, 27:133-149.

70. Attaran D, Lari SM, Khajehdaulee M, Ayatollahi H, Towhidi M, Asnaashari A, Marallu HG, Mazloomi M, Mood MB: Highly sensitive C-reactive protein levels in Iranian patients with pulmonary complication of sulfur mustard poisoning and its correlation with severity of airway diseases. Hum Exp Toxicol 2009, 28:739-745

71. Rasmussen F, Mikkelsen D, Hancox RJ, Lambrechsten J, Nybo M, Hansen HS, Siersted HC: High-sensitive C-reactive protein is associated with reduced lung function in young adults. Eur Res J 2009, 33:382-388.

72. Lin WY, Yao CA, Wang HC, Huang KC: Impaired lung function is associated with obesity and metabolic syndrome in adults. Obesity 2012, 14:1654-1661.

73. Lawson C, Wolf S: ICAM-1 signalling in endothelial cells. Pharmacol Rep 2009, 61:22-32.

74. Levitt JE, Gould MK, Ware LB, Matthay MA: The pathogenic and prognostic value of biologic markers in acute lung injury. J Intensive Care Med 2009, 24:151-167.

75. Shai I, Pischon T, Hu FB, Ascherio A, Rifai N, Rimm EB: Soluble intercellular adhesion molecules, soluble vascular adhesion molecules and risk of coronary heart disease. Obesity 2012, 14:2099-2106.

76. Masclans JR, Sabater J, Sacanall J, Chacon P, Sabin P, Roca O, Planas M: Possible prognostic value of leukotriene B4 in acute respiratory distress syndrome. Respir Care 2007, 52:1695-1700.

77. Back M: Leukotriene signaling in atherosclerosis and ischemia. Cardiovasc Drug Ther 2009, 23:41-48.

78. Sonar SS, Ehmke M, Marsh LM, Dietze J, Dudda JC, Conrad ML, Renz H, Nockher WA: Clara cell drive eosinophil accumulation in allergic asthma. Eur Respir J 2012, 39:429-438.

79. Nordberg GF, Lundstrom NG, Forsberg B, Hagenbjork-Gustafsson A, Lagerkvist BJ, Nilsson J, Svensson M, Blomberg A, Nilsson L, Bernard A, Dumont $X$, Bertilsson $H$, Eriksson $K$ : Lung function in volunteers before and after exposure to trichloramin in indoor pool environments and asthma in a cohort of pool workers. BMJ Open 2012, 2. doi:10.1136/ bmjopen-2012-000973.

80. Zuurbier M, Hoek G, Oldenwening M, Meliefste K, Krop E, Hazel PVD, Brunekreef B: In traffic air pollution exposure and CC-16, blood coagulation and inflammation markers in healthy adults. Environ Health Perspect 2011, 119:1384-1389.

81. Bystrom J, Amin K, Bishop-Bailey D: Analysing the eosinophil cationic protein - a clue to the function of the eosinophil granulocyte. Respir Res 2011, 12:10.

82. Boekholdt SM, Peters RJG, Hack CE, Day NE, Luben R, Bingham SA, Wareham NJ, Rietsma PH, Khaw KT: IL-8 plasma concentrations and the risk of coronary artery disease in apparently healthy men and women: 
the EPIC Norfolk prospective population study. Arterioscler Thromb Vascular Biol 2004, 24:1503-1508.

83. Wu JT, Wu LL: Linking inflammation and atherosgenesis: soluble markers identified for the detection of risk factors and for early risk assessment. Clin Chim Acta 2006, 366:74-80.

84. Apostolakis S, Vogiatzi K, Amanatidou V, Spandidos DA: Interleukin 8 and cardiovascular disease. Cardiovasc Res 2009, 84:353-360.

85. Araujo JA, Nel AE: Particulate matter and atherosclerosis: role of particle size, composition and oxidative stress. Part Fibre Toxicol 2009, 6:24.

doi:10.1186/1476-069X-12-78

Cite this article as: Elango et al:: Chronic exposure to emissions from

photocopiers in copy shops causes oxidative stress and systematic

inflammation among photocopier operators in India. Environmental Health 2013 12:78.

\section{Submit your next manuscript to BioMed Central and take full advantage of:}

- Convenient online submission

- Thorough peer review

- No space constraints or color figure charges

- Immediate publication on acceptance

- Inclusion in PubMed, CAS, Scopus and Google Scholar

- Research which is freely available for redistribution 